\title{
Peptide substrates for ERK1/2: structure-function studies of serine 31 in tyrosine hydroxylase
}

\author{
John W. Haycock * \\ Department of Biochemistry and Molecular Biology, Louisiana State University Health Sciences Center, 1100-Florida Avenue, New Orleans, LA 70119,
} USA

Received 5 December 2001; received in revised form 1 February 2002; accepted 1 February 2002

\begin{abstract}
The first physiological substrate identified for the extracellular signal-regulated protein kinases (ERKs) is serine 31 in tyrosine hydroxylase (TH), the rate-limiting enzyme in catecholamine biosynthesis. In the present studies, several synthetic peptides modeled after Ser31 in TH were evaluated as in vitro substrates for the ERKs. The phosphorylation of Ser31-containing peptides from type 1 human TH by activated, recombinant ERK2 was found to exhibit catalytic efficiencies $\left(V_{\max } / K_{\mathrm{m}}\right)$ up to 4 -fold higher than that of a synthetic myelin basic protein (MBP)-based peptide. Both types of peptides were also tested using extracts from PC12 cells (untreated or treated with nerve growth factor (NGF)). Although, the phosphorylation of the MBP peptide by extracts of PC12 cells was higher than that of the Ser31 peptide, the relative treatment-dependent increase was much greater for the Ser31 peptide and more closely mimicked the pattern of ERK phosphorylation, suggesting that the latter peptide may be a more specific substrate for the ERKs. (C) 2002 Elsevier Science B.V. All rights reserved.
\end{abstract}

Keywords: Mitogen-activated protein kinase; Protein phosphorylation; Kinase assays

\section{Introduction}

The family of extracellular signal-regulated protein kinases (ERKs) cloned by Cobb and coworkers (Boulton et al., 1991) are proline-directed Ser/Thr kinases. Originally described by Ray and Sturgill $(1987,1988)$ as insulin-stimulated, microtubule-associated protein $2 \mathrm{ki}$ nase (MAPK) activity, the ERKs also phosphorylate myelin basic protein (MBP) avidly in vitro (Ahn et al., 1990). Based upon structure/function studies, Pelech and coworkers (Clark-Lewis et al., 1991) developed a synthetic peptide substrate for the ERKs modeled after the Thr97 phosphorylation site in MBP (Erickson et al., 1990). This peptide (APRTPGGRR) contains the-P-X$\mathrm{S} / \mathrm{T}-\mathrm{P}$-motif thought to represent the consensus substrate recognition sequence for the ERK1 (44 kDa) and ERK2 (42 kDa) members of the family (Clark-Lewis et al., 1991; Gonzalez et al., 1991). However, MBP can

* Tel.: + 1-504-619-8534; fax: + 1-504-619-8775.

E-mail address: jhayco@1suhsc.edu (J.W. Haycock). also be phosphorylated by ERK2 at Thr94 (Robinson et al., 1996) and by numerous other protein kinases at other sites (cf. Erickson et al., 1990); and, the selectivity of APRTPGGRR as substrate for ERK versus other protein kinase activities was not tested. Based upon studies by Soonyang et al. (1996), an alternative peptide substrate termed ERKtide was developed (Robinson et al., 1996). Although, relatively efficient as a substrate for catalysis-poor ERK mutants, its kinetic characteristics were only quantitatively superior to previously described peptide substrates.

As noted by Clark-Lewis et al. (1991), while the presence of a prolyl residue at the -2 position enhances the $V_{\max }$ of peptide phosphorylation, its presence is not essential. In fact, the phosphorylation site of the first physiological substrate of ERK1/ERK2 to be described-Ser31 in tyrosine hydroxylase (TH) (Haycock et al., 1992) - does not possess such an upstream prolyl residue (rodent: -EAVTS ${ }^{31} \mathrm{PRF}-$; other mammals: -EAIMS ${ }^{31} \mathrm{PRF}-$ ). In fact, recently, ERK-dependent phosphorylation of Ser31 was found to be responsible for depolarization-dependent increases in 
catecholamine biosynthesis in PC12 cells (Salvatore et al., 2001). These two observations prompted the present studies in which peptide substrates modeled after Ser31 in TH were evaluated for kinetic characteristics as ERK substrates and for specificities in assays of ERK activation in cell extracts.

\section{Materials and methods}

\subsection{Materials}

Purified peptides were obtained from Sigma (St. Louis, MO) or custom synthesized by LSUMC Core Laboratories. Purified, activated ERK1 was a gift from Dr M.H. Cobb (Univ Texas Southwestern Med Ctr), and purified, recombinant, activated ERK2 was a gift from Dr N.G. Ahn (Univ Colo, Boulder). Except as indicated below, other materials were obtained from Sigma.

\subsection{PC12 cells}

PC12 cells were maintained in culture and seeded into collagen-coated 12-well plates prior to experiments (Haycock et al., 1992). Cells were treated with and without added $100 \mathrm{ng} / \mathrm{ml}$ 7S nerve growth factor (NGF) for up to $8 \mathrm{~h}$ and harvested after either solubilization with sodium dodecyl sulfate solution (Haycock, 1993a) (for blot immunolabeling) or trituration in an ice-cold lysis solution of $50 \mathrm{mM} \beta$-glycerophosphate, $1 \mathrm{mM}$ EGTA, $1 \mathrm{mM}$ dithiothreitol, $1 \mathrm{mM}$ benzamidine (Kodak), $0.1 \mathrm{mM} \mathrm{Na} \mathrm{VO}_{4}, 10 \mu \mathrm{g} / \mathrm{ml}$ leupeptin, $0.05 \%$ Tween 20 (for kinase assays). Supernatants from the latter samples were generated by sonication and centrifugation $(20 \mathrm{~min}$ at $10000 \times g)$ in a refrigerated centrifuge (Savant, Farmingdale, NJ). In some experiments, ERK1/2 was isolated by immunoprecipitation with anti-pan ERK1/2 (Ortiz et al., 1995) and protein ASepharose prior to assaying kinase activity.

\subsection{ERK activity assays}

Aliquots of supernatants or ERK1/2 immunoprecipitates (suspended in lysis solution) were mixed with substrate (1 mM final, unless stated otherwise) at $4{ }^{\circ} \mathrm{C}$. Phosphorylation reactions were initiated by addition of an equal volume of assay buffer containing $\left[\gamma-{ }^{32} \mathrm{P}\right] \mathrm{ATP}(\mathrm{NEN})$ and $\mathrm{Mg}$ and allowed to proceed for $10 \mathrm{~min}$ at $30{ }^{\circ} \mathrm{C}$, after which duplicate $20 \mu \mathrm{l}$ aliquots were spotted onto Whatman P81 paper [as would be predicted by the presence of multiple basic residues in the peptides, the ability of $\mathrm{P} 81$ paper to bind $>90 \%$ of each of the peptides used in Tables 2 and 3 was confirmed by UV detection following RP-HPLC]. The final reaction mixtures $(50 \mu \mathrm{l})$ contained $50 \mathrm{mM} \beta$ - glycerophosphate, $10 \mathrm{mM} \mathrm{MgCl} 2,1 \mathrm{mM}$ EGTA, $1 \mathrm{mM}$ dithiothreitol, $1 \mathrm{mM}$ benzamidine, $0.1 \mathrm{mM}$ ATP, 0.1 $\mathrm{mM} \mathrm{Na} \mathrm{VO}_{4}, 10 \mu \mathrm{M}$ calmidazolium, $2 \mu \mathrm{M}$ peptide inhibitor of cyclic AMP-dependent protein kinase (TTYADFIASGRTGRRNALHD), $10 \mu \mathrm{g} / \mathrm{ml}$ leupeptin, $0.025 \%$ Tween 20 .

\subsection{Blot immunolabeling}

The levels of diphosphorylated ERK protein were quantitated as described elsewhere in detail (Ortiz et al., 1995; Haycock, 1996). Aliquots were subjected to SDSPAGE ( $9 \%$ slab gels), and proteins in the separating gel were transferred electrophoretically to nitrocellulose sheets. After protein staining (Ponceau S) was documented xerographically, transfers were then destained/ quenched in blot buffer (Dulbecco's phosphate-buffered saline (GIBCO), $10 \mathrm{mM}$ Tris $-\mathrm{HCl}(\mathrm{pH} 7.6), 0.05 \%$ (w/v) Tween $20,0.01 \%$ sodium azide) containing $1 \%(\mathrm{w} / \mathrm{v})$ polyvinylpyrrolidone (Haycock, 1993b). Transfers were then incubated ( $1 \mathrm{~h}$, room temperature) sequentially with primary antibody (Promega, Madison, WI), swine anti-rabbit secondary antibody $(0.8 \mu \mathrm{g} / \mathrm{ml}$; DAKO $)$, and ${ }^{125}$ I-protein A $(200 \mathrm{kcpm} / \mathrm{ml}$; NEN $)$ in blot buffer containing polyvinylpyrrolidone. Transfers were rinsed five times $(2 \times 2,3 \times 5 \mathrm{~min})$ with blot buffer after incubation with each of the reagents. Immunoreactivity was visualized autoradiographically (XAR film; Kodak), quantitated by gamma counting of excised bands and blanks, and expressed as relative protein levels by interpolation from standard curves run on the same blot (Haycock, 1993a).

\section{Results and discussion}

\subsection{Phosphorylation of peptide substrates by ERKs}

The first Ser31-based peptide used as an ERK substrate (KQAEAVTSPR), although phosphorylated by both ERK1 and ERK2, incorporated considerably less ${ }^{32} \mathrm{P}$ than did MBP (Haycock et al., 1992). As shown in Table 1, ERK1-dependent phosphorylation of MBP, MBP peptide, and EGF receptor peptide was substantially higher than that of the rat TH-Ser31 peptide used in the original report. ${ }^{32} \mathrm{P}$ incorporation into this peptide was, however, higher than that into $\mathrm{TH}$ peptides containing either Ser8, Ser19, or Ser40. While variation of the rat TH-Ser31 peptide sequence improved ERKcatalyzed ${ }^{32} \mathrm{P}$ incorporation (Table 2 , top), ${ }^{32} \mathrm{P}$ incorporation into cognate and other type 1 human TH-Ser31 peptides was higher (Table 2, middle). Inclusion of the endogenous FIGRR sequence downstream of the phosphorylation site, as well as extending the upstream sequence, improved the phosphorylation of the Ser31containing peptides. [Subsequent experiments showed 
Table 1

Phosphorylation of substrates by ERK1

\begin{tabular}{|c|c|c|}
\hline $\begin{array}{l}\text { SUBSTRATE } \\
\text { SOURCE }\end{array}$ & SEOUENCE & $\begin{array}{c}\text { RELATIVE }{ }^{32} \mathrm{P} \\
\text { INCORPORATION }\end{array}$ \\
\hline & & $\%$ of $M B P$ \\
\hline MBP (protein) & ...KNIVTPRTPPPS ... & 100 \\
\hline MBPtide (Thr97) & APRTPGGRR & 28 \\
\hline EGF RECEPTOR (Thr669) & RRELVEPLTPSGEA & 13 \\
\hline \multirow[t]{3}{*}{ BRADYKININS } & RPPGFSPFR & $<1$ \\
\hline & RPGFSPFR & $<1$ \\
\hline & RPPGFSPL & $<1$ \\
\hline OTHER & GRGDSPK & $<1$ \\
\hline \multicolumn{3}{|l|}{$\underline{\mathrm{TH} \text { (rat) }}$} \\
\hline Ser8 & PTPSAPSPOPK & $<1$ \\
\hline Ser19 & RRAVSEODAK & $<1$ \\
\hline Ser31 & KQAEAVTSPR & 5 \\
\hline Ser40 & GRROSLIEDAR & $<1$ \\
\hline
\end{tabular}

Each value represents the median of three independent determinations, performed in duplicate. While all peptides were assayed at a concentration of $1 \mathrm{mM}$, MBP phosphorylation - given as a frame of reference at a concentration typically used in such assays-was assayed at $20 \mu \mathrm{M}$. ${ }^{32} \mathrm{P}$ incorporation into MBPtide was $330 \mathrm{nmol} / \mathrm{min}$ per $\mathrm{mg}$ under the assay conditions used.

that the isoleucine could be omitted without effect upon phosphorylation rate (data not shown).] By contrast, peptides derived from the type 2 human $\mathrm{TH}$ splice variant (which results in the addition of the residues VRGQ immediately upstream of Ser31) were relatively poor substrates for ERK2 (Table 2, bottom).

Steady-state kinetic analyses of several of the peptide substrates is presented in Table 3. Unlike MBP, which has a $K_{\mathrm{m}}$ in the range of $10-50 \mu \mathrm{M}$ (Robinson et al., 1996; Kameshita et al., 1997; Prowse et al., 2000), all of the peptides tested had $K_{\mathrm{m}(\mathrm{app})} \mathrm{s}$ ranging from 0.6 to 2.0 mM. Kameshita et al. (1997) reported a $K_{\mathrm{m}}$ for MBPtide of $1.6 \mathrm{mM}$, which they were able to lower to $74 \mu \mathrm{M}$ by conjugating multiple MBPtide molecules to poly(Lys) 87 . Notably, the original rat TH-Ser31 peptide exhibited the lowest catalytic efficiency $(V / K)$, whereas substantially higher efficiencies were obtained with type 1 human THSer31 peptides and ERKtide, which contains the FGRR sequence downstream of the phosphorylation site [note that Prowse et al. (2000) incorrectly attribute ERKtide entirely to the consensus sequence for ERK1 (TGPLSPGPF) described by Soonyang et al. (1996). ERKtide was developed in my laboratory from a portion (TGPLSP) of the consensus sequence, to which
I added the $\mathrm{N}$-terminal $\mathrm{A}$ and $\mathrm{C}$-terminal FGRR based upon results with the type 1 human TH-Ser31 peptides]. The present $K_{\mathrm{m}(\mathrm{app})}$ of ERKtide $(0.6 \mathrm{mM})$ is comparable with that described previously $(0.45 \mathrm{mM}$, Robinson et al., 1996; although see also Prowse et al., 2000).

\subsection{Comparison of in vitro assays of ERK activation in situ}

There are currently several approaches which can be used to assay the state of ERK activation within cells. These include in vitro phosphorylation of exogenous substrate by cellular extracts, in vitro phosphorylation of exogenous substrate by ERK immunoprecipitates, ingel phosphorylation of exogenous substrate, and quantitative blot immunolabeling of the diphosphorylated forms of ERK1/2. The first, and easiest, assay requires that the substrate be selectively phosphorylated by ERK1/2. And, whereas MBP exhibits better in vitro characteristics of phosphorylation by ERK than any of the peptides studied here, MBP can be phosphorylated by a number of known and unknown (see below) cellular protein kinases. Whereas immunoprecipitation prior to kinase assay eliminates contributions from 
Table 2

Phosphorylation of TH Ser31-containing peptides by ERK2

\begin{tabular}{lc}
\hline TH-Ser31 & RELATIVE ${ }^{32} \mathrm{P}$ \\
SEQUENCE & INCORPORATION \\
\hline
\end{tabular}

RAT:

KQAEAVTSPR

AVTSPRFIGRR

9

EAVTSPRFIGRR

type 1 HUMAN:

EAIMSPRFK

AIMSPRFIGRR

EAIMSPRFIGRR

YOAEAIMSPRFIGRRO

YOAEAIMSPRFIGRR-NH2

type 2 HUMAN:

IMVRGOSPR
YIMVRGOSPR
EAIMVRGOSPRFK

Each value represents the median of three independent determinations, performed in duplicate. 100 percent ${ }^{32} \mathrm{P}$ incorporation reflects 3.3 $\mu \mathrm{mol} / \mathrm{min}$ per $\mathrm{mg}$ under the conditions of these assays.

extraneous protein kinases, this requires additional steps and costly reagents as well as further steps to ensure that quantitative immunoprecipitation has been achieved. Similarly, blot immunolabeling analyses require careful attention to ERK transfer efficiencies, which are low and vary with sample composition (Ortiz et al., 1995), and the sample throughput is limited by the number of SDS-PAGE wells available, several of which must be dedicated to a standard curve on each gel.

Fig. 1 (upper panels) illustrates that the latter two assays produce a qualitatively similar pattern of ERK activation in PC12 cells during prolonged treatment with NGF. However, using the simpler assay of cellular extracts, as shown in the lower panels of Fig. 1, the results obtained vary qualitatively depending upon the substrate used to measure ERK activity. Much higher control levels of protein kinase activity were obtained using either MBP or MBPtide, despite the presence of EGTA, calmidazolium, and cAMP-dependent protein kinase inhibitor in the assay mix. In addition, both the

Table 3

Kinetic constants of peptide substrates for ERK2

\begin{tabular}{llll}
\hline SUBSTRATE & $\mathrm{K}_{\text {m(app) }}$ & $\mathrm{V}_{\text {max(app) }}$ & $\mathrm{V} / \mathrm{K}$ \\
\hline$m M$ & \multicolumn{2}{c}{ relative }
\end{tabular}

MBPtide:

$\begin{array}{llll}\text { APRTPGGRR } & 2.0 & 46 & 23\end{array}$

rat TH:

KQAEAVTSPR

1.8

9

human TH type 1 :

EAIMSPRFK

YQAEAIMSPRFIGRRO

1.4

42

28

1.0

80

80

ERKtide:

$\begin{array}{llll}\text { ATGPLSPFGRR } & 0.6 & 82 & 136\end{array}$

Each value represents the median of three independent determinations, performed in duplicate. The apparent $V_{\max }$ of ERKtide was $9.4 \mu \mathrm{mol} /$ min per $\mathrm{mg}$.

pattern and percent stimulation of ERK activity differed from that measured by either the ERK immunoprecipitation or blot immunolabeling assays. In contrast, the percent stimulation of ERK activity in the immunoprecipitation and blot immunolabeling assay was faithfully reproduced using either a type 1 human TH-Ser31 peptide or ERKtide as substrate in the cell extract assay. A similar pattern of results was also seen in phorbol ester-treated PC12 cells (data not shown) and K562 cells (N.G. Ahn, personal communication), indicating that the data presented in Fig. 1 is not restricted to $\mathrm{PC} 12$ cells and/or NGF treatment.

Thus, the validity of assays of ERK activity in cellular extracts depends upon the substrate used, and the present data indicate that prior immunoprecipitation is required if MBP or MBPtide is chosen as a substrate. However, some caution even with this approach is warranted given the recent observation (Zhang et al., 2001) that, when over expressed in HeLa or HEK 293 cells, p38 MAP kinase is present in ERK1/2 immunoprecipitates and phosphorylates MBP. Alternatives, such as in-gel kinase assays precast with MBP, are expensive and, while the separation of ERK1 and ERK2 by molecular mass can isolate their individual activities, issues of renaturation and equilibration of reaction solutions make such assays more cumbersome and less desirable than, e.g. blot immunolabeling with antidiphosphoERK antibodies. By contrast, the present data indicate that in situ ERK activation can be accurately assessed in cellular extracts by using either 
KINASE ASSAY OF ERK IP BLOT ASSAY of pYpT-ERK1
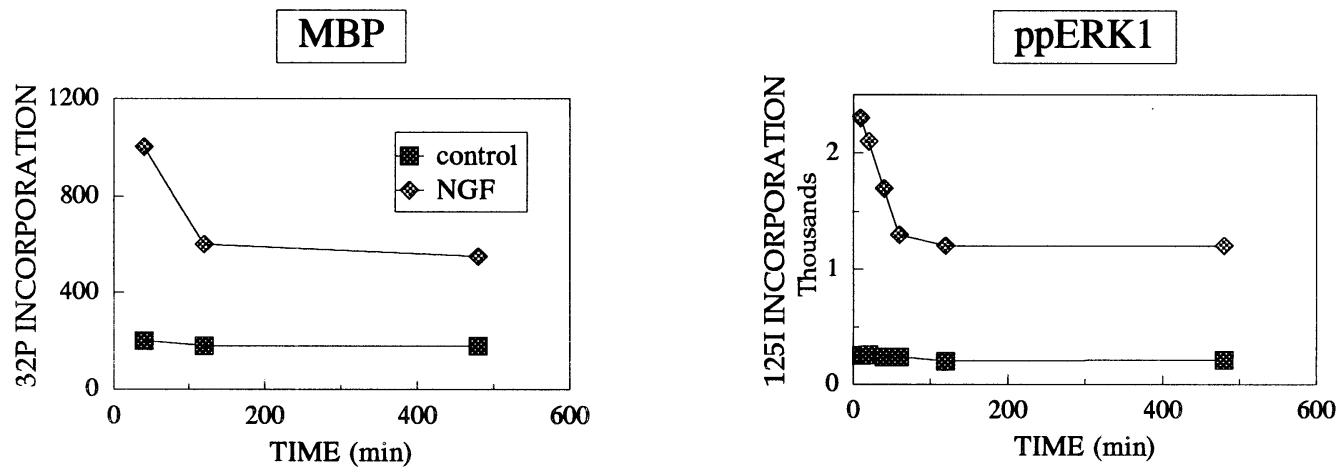

KINASE ASSAYS OF CELL EXTRACTS
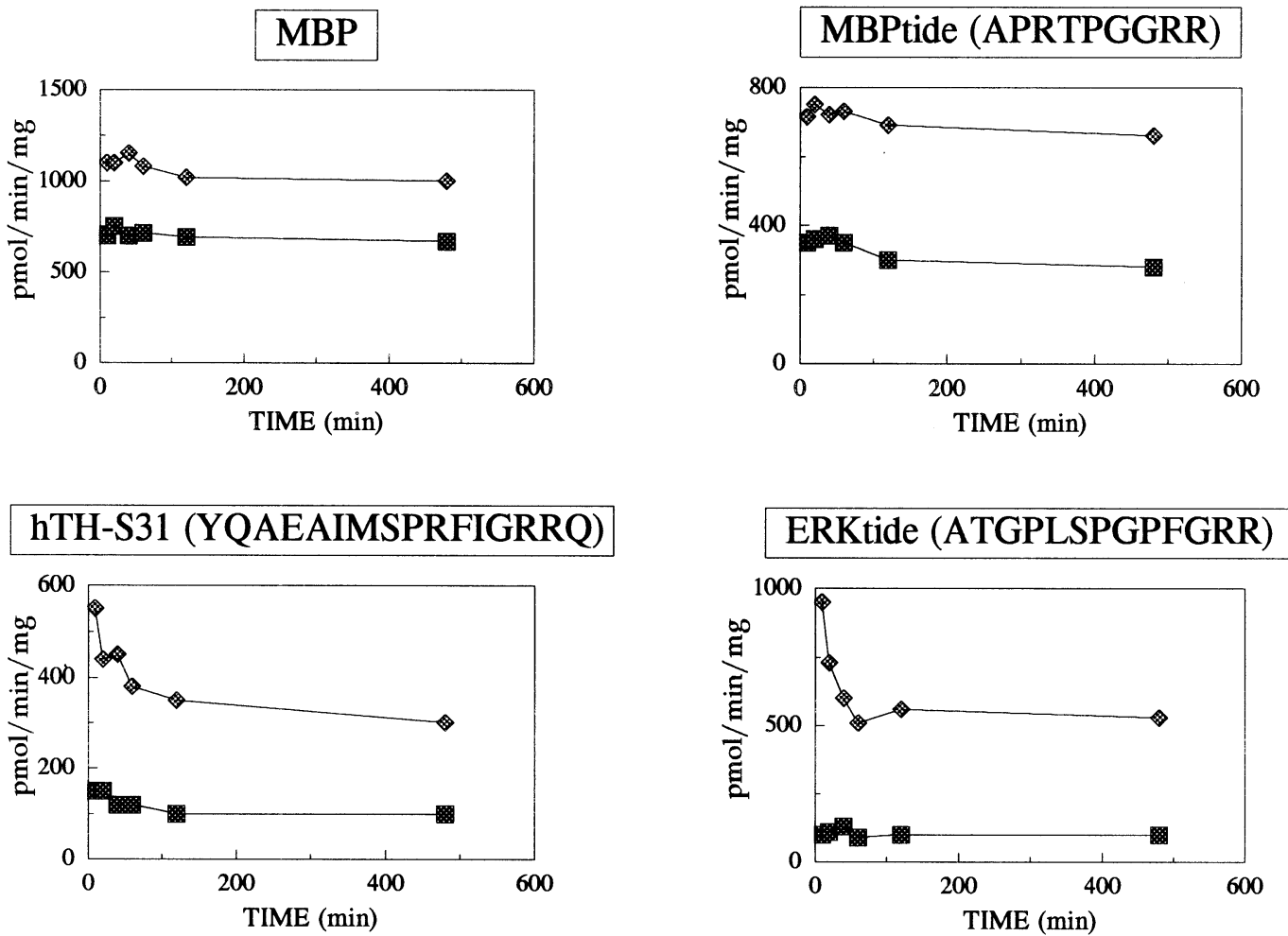

Fig. 1. Assays of ERK activity in PC12 cells. Cells were treated with (diamonds) or without (squares) $100 \mathrm{ng} / \mathrm{ml} \mathrm{NGF}$ for up to $8 \mathrm{~h}$ before harvesting the samples and assaying them as described under Section 2. Values represent the averages from two independent samples analyzed in duplicate. IP, immunoprecipitation.

type 1 human TH-Ser31 peptide or ERKtide as exogenous substrate in a relatively high throughput system.

\section{Acknowledgements}

This research was supported by USPHS grants MH00967, MH55208, and NS25134.

\section{References}

Ahn NG, Weiel JE, Chan CP, Krebs EG. Identification of multiple epidermal growth factor-stimulated protein serine/threonine kinases from Swiss 3T3 cells. J Biol Chem 1990;265:11487-94.

Boulton TG, Nye SH, Robbins DJ, Ip NY, Radziejewska E, Morgenbesser SD, DePinho RA, Panayotatos N, Cobb MH, Yancopoulos GD. ERKs: A family of protein-serine/threonine kinases that are activated and tyrosine phosphorylated in response to insulin and NGF. Cell 1991;65:663-75. 
Clark-Lewis I, Sanghera JS, Pelech SL. Definition of a consensus sequence for peptide substrate recognition by $\mathrm{p} 44^{m p k}$, the meiosisactivated myelin basic protein kinase. J Biol Chem 1991;266:15180-4.

Erickson AK, Payne DM, Martino PA, Rossomondo AJ, Shabanowitz J, Weber MJ, Hunt DF, Sturgill TW. Identification by mass spectrometry of threonine 97 in myelin basic protein as a specific phosphorylation site for mitogen-activated protein kinase. J Biol Chem 1990;265:19728-35.

Gonzalez FA, Raden DL, Davis RJ. Identification of substrate recognition determinants for human ERK1 and ERK2 protein kinases. J Biol Chem 1991;266:22159-63.

Haycock JW. Multiple forms of tyrosine hydroxylase in human neuroblastoma cells: quantitation with isoform-specific antibodies. J Neurochem 1993a;60:493-502.

Haycock JW. Polyvinylpyrrolidone as a blocking agent in immunochemical studies. Anal Biochem 1993b;208:397-9.

Haycock JW. In vivo activation of ERK1 and ERK2 in regions of rat brain. Neural Notes 1996;2:14.

Haycock JW, Ahn NG, Cobb MH, Krebs EG. ERK1 and ERK2, two microtubule-associated protein 2 kinases, mediate the phosphorylation of tyrosine hydroxylase at serine 31 in situ. Proc Natl Acad Sci USA 1992;89:2365-9.

Kameshita I, Ishida A, Fujisawa H. A new peptide conjugate as a highly specific substrate for MAP kinase. J Biochem 1997;122:168 72.

Ortiz J, Harris HW, Guitart X, Terwilliger RZ, Haycock JW, Nestler EJ. Extracellular signal-regulated protein kinases (ERKs) and ERK kinase (MEK) in brain: regional distribution and regulation by chronic morphine. J Neurosci 1995;15:1285-97.
Prowse CN, Hagopian JC, Cobb MH, Ahn NG, Lew J. Catalytic reaction pathway for the mitogen-activated protein kinase ERK2. Biochemistry 2000;39:6258-66.

Ray LB, Sturgill TW. Rapid stimulation by insulin of a serine/ threonine kinase in 3T3-L1 adipocytes that phosphorylates microtubule-associated protein 2 in vitro. Proc Natl Acad Sci USA 1987;84:1502-6.

Ray LB, Sturgill TW. Characterization of insulin-stimulated microtubule-associated protein kinase: Rapid isolation and stabilization of a novel serine/threonine kinase from 3T3-L1 cells. J Biol Chem 1988;263:12721-7.

Robinson MJ, Harkins PC, Zhang J, Baer R, Haycock JW, Cobb MH, Goldsmith EJ. Mutation of position 52 in ERK2 creates a nonproductive binding mode for adenosine 5 '-triphosphate. Biochemistry 1996;355:5641-6.

Salvatore MF, Waymire JC, Haycock JW. Depolarization-stimulated catecholamine biosynthesis: Involvement of protein kinases and tyrosine hydroxylase phosphorylation sites in situ. J Neurochem 2001;79:349-60.

Soonyang Z, Lu KP, Kwon YT, Tsai L-H, Filhol O, Cochet C, Brickey DA, Soderling TR, Bartleson C, Graves DJ, DeMaggio AJ, Hoekstra MF, Blenis J, Hunter T, Cantley LC. A structural basis for substrate specificities of protein serine/threonine kinases: Primary sequence preference of casein kinases I and II, NIMA, phosphorylase kinase, calmodulin-dependent kinase II, CDK5, and ERK1. Mol Cell Biol 1996;16:6486-93.

Zhang H, Shi X, Hampong M, Blanis L, Pelech S. Stress-induced inhibition of ERK1 and ERK2 by direct interaction with p38 MAP kinase. J Biol Chem 2001;276:6905-8. 